\title{
NEWS AGGREGATOR DAN NILAI-NILAI JURNALISME: STUDI PENYAJIAN BERITA PADA BERITAGAR.ID
}

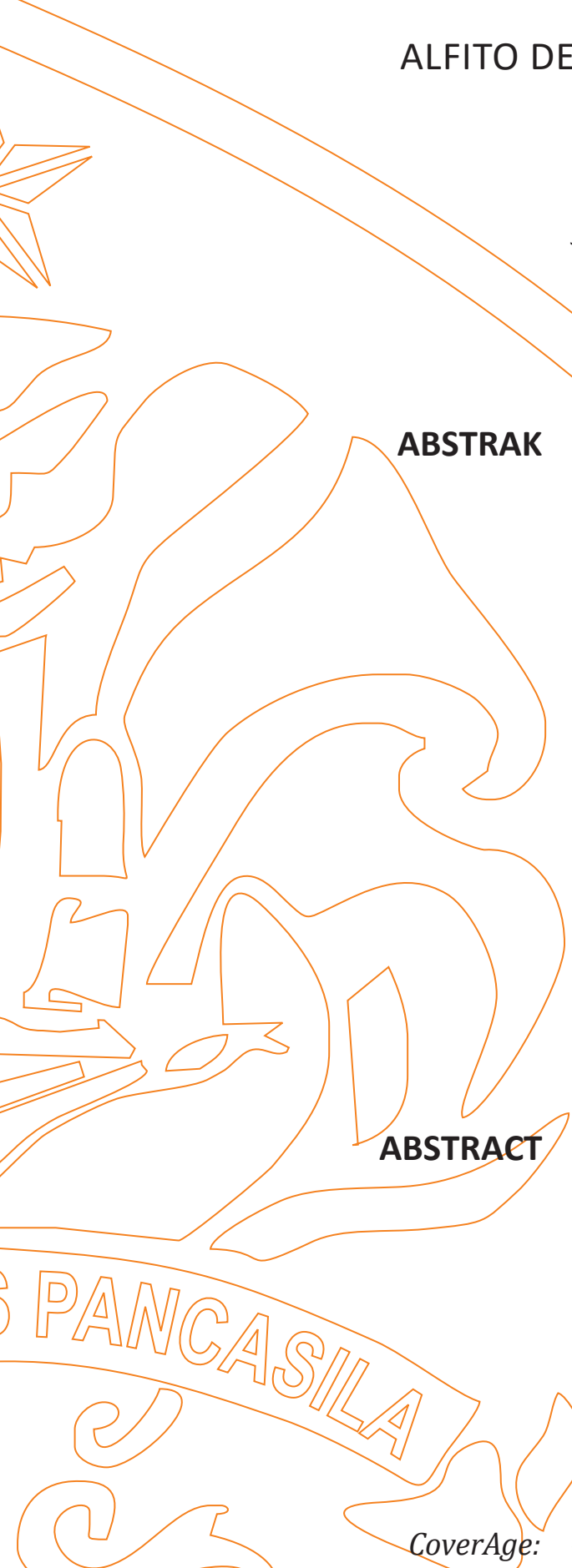

Journal of Strategic Communication

Vol. 10, No. 1, Hal. 27-36. September 2019 Fakultas Ilmu Komunikasi, Universitas Pancasila
Fakultas IImu Komunikasi Universitas Pancasila Jalan Srengseng Sawah Jagakarsa Jakarta Selatan 12640 Email: deannovas@gmail.com
News aggregator adalah profesi baru yang muncul seiring dengan melimpahnya informasi. Artikel ini bertujuan untuk menganalisis hasil praktek kerja news aggregator yang sebagian besar dirangkap perannya oleh para jurnalis di Indonesia. Para news aggregators yang juga bekerja sebagai jurnalis, memiliki pedoman etika profesi dalam koridor proses jurnalistik di mana kode etik jurnalistik harus dijalankan, elemen jurnalisme perlu dilakukan, serta susunan berita dengan informasi sesuai $5 \mathrm{~W} 1 \mathrm{H}$. Pedoman ini menjadi konsep menganalisis isi berita yang pada penelitian ini difokuskan pada isi berita dalam beritagar.id. Hasil penelitian menunjukkan bahwa kantor agregasi berita, dalam hal ini beritagar.id, menjalankan proses jurnalistik sesuai nilai-nilai jurnalisme dengan bantuan artificial intelegent. Namun demikian, masih belum diakui sebagai jurnalisme mengingat prinsip turun ke lapangan untuk mengambil data langsung menjadi hal penting dalam proses verifikasi data produk jurnalistik. Menariknya adalah hasil penelitian ini menunjukkan adanya peningkatan pemahaman tentang proses jurnalistik dalam media aggregator pada jurnalis senior yang mengawali karirnya di media mainstream.

Kata Kunci: Media, jurnalisme, news aggregator, nilai jurnalisme

News aggregator is a new profession that emerges along with the abundance of information. This article aims to analyze the results of the work practices of the news aggregator whose roles are mostly held by journalists in Indonesia. The news aggregators who also work as journalists, have professional ethics guidelines in the corridor of the journalistic process where the journalistic code of ethics must be implemented, the elements of journalism need to be carried out, as well as the composition of/news with information in accordance with $5 \mathrm{~W} 1 \mathrm{H}$. This guideline becomes the concept of analyzing news content which in this study is focused on news content in beritagar.id. The results showed that the news aggregation office, in this case beritagar.id, ran a journalistic process according to journalism values. However, it is still not recognized as journalism since the principle of going to the field to collect data directly is important in the process of verifying journalistic product data. Interestingly, the results of this study indicate an increase in understanding of the journalistic process in media aggregators for senior journalists who began their careers in the mainstream media.

Keywords: Media, journalism, news aggregator, journalism value 


\section{PENDAHULUAN}

Berita dan bukan berita dibedakan dengan beberapa pakem. Pakem yang umum dikenal adalah adanya konten informasi yang menjawab pertanyaan " $5 W 1 H$ ", adanya kebaruan, dan memiliki lead berita yang formatnya berbentuk piramida terbalik dengan penjelasan yang paling penting menempati kalimat pertama dalam lead, diikuti informasi lainnya yang menunjang. Namun, pakem ini kemudian bergeser ketika teknologi masuk dalam proses jurnalistik, dan menjadi salah satu unsur penting dalam menyampaikan berita ke publik.

Pergeseran yang terjadi antara lain adalah kompetisi penyajian berita tidak lagi pada kebaruan dan eksklusifitas berita tetapi pada kecepatan mengunggah berita dan frekuensi klik. Internet dan adanya kemajuan telekomunikasi memberikan individu kemampuan untuk mengakses, bahkan mengunggah beragam informasi termasuk berita, kapanpun dan di manapun. Hal ini kemudian menjadi salah satu sebab terjadinya pergeseran pakem $5 \mathrm{~W} 1 \mathrm{H}$ dalam menyajikan berita ke publik. Berita yang disajikan tidak lagi harus memenuhi 5W1H, What, When, Where saja sudah bisa diunggah ke dalam media sebagai informasi atau berita.

Pembuat dan atau pengunggah berita tidak lagi hanya jurnalis, setiap individu dapat mengunggah atau membuat berita. Profesionalisme dan privilege jurnalis berkurang. Kompetisi menyajikan informasi terbaru, yang dapat dianggap sebagai berita, terjadi bukan saja antar jurnalis yang bekerja dari beragam organisasi media tetapi antar individu atau warga Negara yang memiliki gadget, sehingga dikenal adanya Citizen Jurnalism atau jurnalis warga dalam konteks berkembangnya tehnologi komunikasi dalam proses jurnalistik. Isu yang kemudian muncul adalah profesionalisme dan pemahaman etika terkait penyajian berita di beragam media.

Indonesia memiliki sekitar tiga ratus juta penduduk, dan setiap individu dikenal memiliki gadget setidaknya satu, dan memiliki setidaknya satu akun media sosial di mana mereka dapat mengunggah informasi yang dapat menjadi berita. Hal ini memberikan kemungkingan adanya 300 juta laporan peristiwa dalam 300 juta akun media yang dimiliki. Terbayang betapa banyaknya berita yang disajikan ke publik dalam watu waktu. Belum lagi sifat internet yang global dan tidak memiliki batas. Akan lebih banyak lagi informasi yang dapat diterima oleh satu individu. Sementara informasi yang diunggah oleh beragam individu perlu kualitasnya perlu diperhatikan atau dipertanyakan, mengingat tidak semua individu memiliki pengetahuan tentang etika penyajian berita. Hal ini kemudian memunculkan masalah baru di masyarakat.

Selain itu, meningkatnya jumlah media mainstream dan online juga mendukung meningkatnya pilihan informasi yang bisa diambil oleh publik. Data media di Indonesia saat ini diperkirakan ada media online atau media siber yang mencapai angka 43.300, angka yang sangat banyak dibandingkan dengan media lainnya. Namun jumlah yang tercatat sebagai media profesional yang lolos syarat pendataan pada 2014 hanya berjumlah 211 media online saja yang terverifikasi. Angka ini menyusut pada tahun 2015 menjadi 168 media online (Dewan Pers, 2018). Setahun kemudian, Desember 2016, Dewan pers mencatat yang terdaftar sebagai media online hanya 234, padahal yang ada di masyarakat keseluruhan situs berita online di Indonesia diidentifikasi berjumlah 43.400 situs. Banyaknya situs online dengan beragam informasi tersaji untuk masyarakat Indonesia. Artikel ini memfokuskan bahasan dalam konteks banyaknya informasi yang dapat diunggah dan diakses individu, muncul agregasi berita yang dilakukan oleh news aggregator terkait nilai-nilai jurnalisme.

Agregasi berita mulai menjamur sejak abad ke 18 dan 19, dengan menyalin dan menerbitkan kembali artikel dari koran dengan berbagai cara tanpa mengindahkan penulis berita atau copyright dari artikel aslinya (Coddington, 2019). News aggregation atau dalam bahasa Indonesia disebut agregasi berita didefinisikan oleh Coddington (2019) sebagai proses mengambil berita dari sumber-sumber yang telah diterbitkan, kemudian membentuk kembali berita, dan menerbitkannya kembali dalam bentuk berita yang lebih singkat dalam satu sajian. Aggregation dalam era digital itu sendiri dapat diklasifikasi dalam tiga tipe, yaitu yang memiliki fokus pada menyediakan wadah dari konten atau sebagai content host (1), kedua adalah agregasi dengan tipe indexing atau mengkategorikan content secara berbeda dari konten lain yang sudah ada atau sebagai the gateway (2), tipe ketiga adalah aggregator tradisional yang memiliki lisensi atas seluruh teks konten atau full text aggregator (3). Beberapa tahun belakangan ini, agregasi berita semakin berkembang biak dengan penggunaan mesin aggregator yang canggih dalam mengumpulkan artikel atau menemukan berita, mengolah berita, lalu dalam menyajikan berita. Artikel ini bertujuan untuk (1) menggambarkan bahwa proses jurnalistik, yang diartikan dengan mengumpulkan data, menulis dan mengedit berita, 
lalu menyajikan berita itu, masih tetap sama, namun peran jurnalis banyak diambil alih oleh tehnologi, dan (2) memberikan paparan tentang nilai jurnalisme pada sajian berita yang telah diagregasi.

Namun dalam beberapa kajian terdahulu disebutkan bahwa agregasi berita banyak melanggar pedoman jurnalistik, atau memunculkan fenomenafenomena yang perlu dikaji bukan saja pada profesionalisme jurnalis, proses jurnalistik, etika jurnalisme dan etika bisnis media, serta banyak hal lain yang juga menjadi diskusi dari peran aggregator berita dalam konteks jurnalisme. Salah satu diskusi dan kajian yang mengangkat konteks dan isu yang mengemuka ketika agregasi berita muncul adalah kajian Joan Calzada dan Ricard Gil (2017). Mereka menggambarkan tentang what do news aggregator do? (evidence from google news in spain and germany).

Hasil yang menyebutkan bahwa aggregator news sudah masuk kedalam ranah oposisi di mana penerbit berita yang menganggap aggregator sebagai pengendara, bebas yang menjual kembali konten meereka. Masalah ini jelas melanggar kode etik, hak cipta, hingga profesionalisme dan bisnis media. Diskursus yang terjadi mengemuka dan akhirnya mencapai puncaknya ketika mendorong munculnya amandemen undang-undang penyebaran konten berita di beberapa negara di pasar eropa. Isu agregasi berita melanggar banyak hal terkait pakempakem yang diagungkan dalam jurnalistik terus berlangsung di beberapa negara eropa sehingga pencegahannya menyangkut adanya pajak, dan hal-hal lain terkait praktek bisnis di negara-negara tersebut. Penelitian ini tidak akan membahas hingga praktek bisnis, bahasan kali ini ditetapkan hanya dari proses jurnalistik dan etika jurnalistik yang merupakan pedoman nilai-nilai jurnalistik. Hasil kajian ini dapat ditindaklanjuti dengan kajian dari sisi bisnis dan etika media.

\section{TINJAUAN PUSTAKA}

\section{Proses Jurnalistik dan Peran Jurnalis}

Jurnalis di Indonesia lahir dengan semangat sebagai pejuang kemerdekaan. Kemerdekaan Indonesia dari penjajah, kemerdekaan Indonesia dari pemerintah yang absolut, dan kemerdekaan Indonesia dalam berekspresi sebagai pemegang kekuatan ke empat setelah Legislatif, Yudikatif dan Eksekutif. Semangat ini masih terus diusung oleh jurnalis Indonesia sesuai dengan penelitian yang dilakukan oleh Hanitzsch (2005) yang menyatakan bahwa jurnalis di Indonesia meneguhkan diri untuk berperan sebagai watchdog untuk membela kepentingan yang lebih besar. Hal ini memiliki implikasi bahwa jurnalis berperan dalam memberikan informasi yang benar, sesuai fakta, bahkan beberapa kajian terdahulu menyebutkan bahwa peran dari jurnalis Indonesia adalah menulis dengan berbagai cara untuk menginformasikan publik tentang isu dengan berpihak pada kepentingan yang lebih besar, serta mempersuasi publik serta pembuat kebijakan agar kepentingan yang lebih besar tersebut terakomodasi (Anom, 2013; Kakiailatu 2007).

Dari UU siber Indonesia ditetapkan adanya hak moral dan hak ekonomi (economic right). Hak moral adalah etika yang perlu diperhatikan ketika mengutip dari media lain, sedangkan hal ekonomi adalah hak yang dimiliki oleh seorang pencipta untuk mendapatkan keuntungan atas ciptaannya. Hak ekonomi ini juga merupakan hak khusus bagi pencipta untuk mengumumkan atau memperbanyak ciptaannya dan memberi izin untuk itu, hak ekonomi ini juga dapat dialihkan kepada pihak lain, hak ekonomi tersebut diantaranya adalah hak pengadaan atas ciptaan, bentuk penggandaan atau perbanyakan ini bisa dilakukan secara tradisional mauun melalui peralatan modern hak penggandaan ini juga mencakup perubahan bentuk ciptaan satu keciptaan lainnya.

Penyebaran tersebut dapat berupa bentuk penjualan, penyewaan atau bentuk lain yang maksudnya agar ciptaan tersebut dikenal oleh masyarakat. Dalam hal ini termasuk pula bentuk dalam Undang-Undang nomer 28 tahun 2014 tentang hak cipta, disebut dengan pengumuman yaitu pembacaan penyuaraan, penyiaran atau penyebaran sesuatu ciptaan dengan menggunakan alat apapun dan dengan cara sedemikian rupa sehingga ciptaan dapat dibaca didengar ataupun dilihat oleh orang lain. Pelanggraan penyebaran konten berita sudah berlaku bagi para media online karena peraturan yang lama sudah di perbaharui. Hak moral adalah hak pencipta untuk mengklaim sebagai pencipta suatu ciptaan dan hak pencipta untuk mengajukan keberatan terhadap setiap perbuatan yang bermaksud mengubah mengurai atau menambah keaslian ciptaannya yang akan merugikan reputasi. Hak moral yang diberikan sejajar dengan hak ekonomi yang dimiliki pencipta atas ciptaannya.

\section{Elemen Jurnalisme dan Kode Etik Jurnalistik}

Praktek jurnalisme di Indonesia telah diarahkan untuk mengikuti kode etik jurnalistik yang ditetapkan dalam UU No. 40 Tahun 1999. Dalam perkembangannya, baik dalam praktek jurnalisme 
maupun terlibatnya media dan teknologi, Indonesia telah memberikan pagar-pagar praktek lalu lalang informasi di Indonesia dalam UU ITE No. 11 tahun 2008 untuk melindungi seluruh pihak dari kejahatan siber. Isi dari UU tersebut seiring dan sejalan dengan 10 elemen jurnalisme yang disampaikan oleh Kovach dan Rosenstiel di banyak kajian terkait proses jurnalistik. Salah satunya adalah mahkota dari jurnalisme yaitu melakukan proses cek dan recheck atau dikenal dengan melakukan verifikasi ke beberapa sumber untuk mendapatkan kebenaran dari peristiwa yang diliput.

Banyaknya pilihan pengambilan informasi yang disediakan oleh media karena adanya internet dan media sosial atau dalam web, menurut Pavlik (2001) adalah pengunjung akan melihat berita terbaru saja yang disiarkan oleh beberapa media, dan jika berita yang dicari tidak bisa diakses, maka pengunjung akan pindah ke website lain untuk mencarinya. Hal ini yang kemudian ditahan oleh para pengelola media. Mereka mencoba memberikan kemudahan bagi pengunjung untuk menemukan berita terbaru yang sesuai dengan perhatiannya. Hal ini kemuidan mendorong munculnya news aggregator, pengumpulan beritaberita terkait satu isu. Yang mendorong terjadinya masalah adalah, ketika pengumpulan satu isu tersebut tidak lagi mengindahkan hak cipta media yang dikumpulkan, atau tidak lagi menempatkan isu tersebut pada konteks terkini yang dapat menyesatkan pengunjung. Lebih dalam terkait pemahaman tentang news aggregator disampaikan pada sub berikut.

\section{News Agregator}

James C. Foust (2014) dalam bukunya menyebutkan bahwa "A news aggregator is a site that does not report news or information itself but rather compiles news and links from other sources". Terdapat berbagai bentuk dan praktik situs agregasi berita yang terdapat di internet. Kimberley Isbell (2010) dalam publikasinya mengategorikan situs agregasi berita ke dalam empat bentuk, yaitu feed aggregators, specialty aggregators, user-curated aggregators, dan blog aggregators. Kajian ini melihat banyaknya kemungkinan muncul aggregator yang menurut Foust cenderung hanya mengkompilasi laporan dari berbagai media tanpa mengutip media yang dikompilasi, membuat media asal informasi diambil menjadi korban dari diabaikannya hak cipta dan etika jurnalistik.

Berita dikurasi oleh news aggregator mengindahkan jurnalis yang melaporkan berita, bahkan organisasi media yang melaporkan, dengan tidak memberikan link berita asal. Jurnalis tidak lagi mengambil informasi dari peristiwa sesungguhnya namun menulis ulang dari berita-berita yang dikumpulkan dari website tanpa mengutip asal data yang mereka ambil. Engelbertus (2017) menyatakan yang menjadi masalah dalam mengumpulkan berita dan menulis ulang adalah jurnalis tidak lagi melihat dan melakukan pengecekan langsung atas informasi ke peristiwa nyata, namun lebih banyak dari website, padahal jurnalis etikanya adalah menerima informasi dan melakukan pengecekan langsung atas peristiwa kepada yang bersangkutan, bukan hanya dari website. Proses jurnalistik yang dilakukan oleh news aggregator ini kemudian dianggap melanggar aspek perlindungan hak cipta atau plagiarisme (Dwiputra, 2011).

Calzada dan Gil (2017) menggambarkan bahwa praktek yang dilakukan news aggregator di Eropa memegaruhi terhadap jumlah kunjungan dan tempat iklan outlet berita. Analisis penelitian ini menunjukkan penurunan yang signifikan di khalayak outlet berita, di mana adanya substitusi yang mungkin telah meningkatkan jumlah kunjungan di luar ke outlet berita setelah penutupan Google news di Spanyol, namun tidak sesuai atau tidak mengganti perhitungan bisnis media. Jurnal yang memberikan ulasan serupa dilakukan oleh Markus dan Pal (2017) mengenai the impact of aggregators on internet news consumption. Hasil penelitian yang menyebutkan mengenai industri berita telah dirugikan oleh perilaku news aggregator sehingga menyerukan peraturan yang menghasilkan sejumlah intervensi kebijakan di berbagai negara di Eropa termasuk Spanyol. Bulan September 2016, Uni Eropa telah mengusulkan peraturan baru untuk para aggregator berita untuk mewajibkan perusahaanperusahaan internet membayar untuk berita yang mereka agregasikan dan disajikan kepada publik.

Kajian-kajian ini kemudian mendorong terbangunnya asumsi bahwa news aggregator memberikan implikasi yang tidak baik dalam bidang jurnalistik. Dari sisi proses jurnalistik dan etika jurnalistik, mereka banyak mengabaikan karena adanya keterlibatan robot dan program di dalamnya dan mengurangi keterlibatan manusia. Sementara etika dalam beragai sisi sangat mengandalkan sisi kemanusiaan dalam penerapannya. Dari sisi etika bisnis, kemunculan aggregator berita menurunkan pendapatan dan kunjungan publik media ke masingmasing media, meskipun mereka mendapatkan ruang liputan yang lebih luas dibandingkan tanpa adanya aggregator berita. 


\section{METODE}

Penelitian ini mengambil pendekatan kualitatif deskriptif, dengan konsep-konsep nilainilai jurnalisme sebagai pisau analisis data yang diambil. Konsep yang digunakan dibatasi pada kode etik jurnalistik dan elemen jurnalisme. Dengan demikian paradigma post positivis diterapkan dalam menganalisis data yang dikumpulkan melalui dokumentasi dan wawancara mendalam. Hasil analisis disusun dengan melihat konsistensi data sesuai konsep yang digunakan tersebut. Konsep kode etik jurnalisme dan elemen jurnalisme menjadi pedoman untuk melakukan proses reduksi data, pengelompokkan data, dan penyajian data yang mengacu pada menjawab pertanyaan penelitian.

\section{HASIL DAN PEMBAHASAN}

Kajian Ulfah (2017) tentang Beritagar.id menggambarkan bahwa beritagar.id adalah media yang menerapkan jurnalisme robot dalam proses produksi beritanya. Beritagar.id. melakukan praktik jurnalisme berbasis teknologi artificial intelligence (Al) yang merupakan inovasi dalam menjalankan produksi berita dengan mengurangi keterlibatan manusia. Profil beritagar:

Gambar 1. Profil Berita Beritagar.id

\section{B ritagarid \\ Merawat Indonesia}

\section{Pada dasarnya Beritagar.id melakukan agregasi, yang menurut KBBI III, bermakna pengumpulan sejumlah benda yang terpisah-pisah menjadi satu. Namun Beritagar.id tidak sekadar membuat daftar tautan, seperti yang dikenal selama ini tentang situs agregasi.}

\section{Redaksi berperan menyunting dan menceritakannya kembali kepada pembaca. Jika datanya tak cukup atau meragukan, maka redaksi akan melakukan verifikasi dan melengkapinya dari sumber lain yang kredibel.}

(Sumber: http://beritagar.id)
Dilihat dari pedoman pemberitaan media siber, jurnal Dewan Pers (2017) menyatakan bahwa meskipun dalam media siber, perlu diperhatikan prinsip kehati-hatian serta mengutamakan tanggungjawab professional daripada pertimbangan komersial. Namun, dalam beritagar.id yang menggunakan Al dan hanya sedikit intervensi manusia, faktor kehati-hatian tidak bisa digunakan. Al hanya memproses data sesuai dengan input program yang diberikan, tanpa memiliki perasaan kehati-hatian. Jika dilihat praktik ini, maka UU yang ada menetapkan dalam konteks jurnalistik di mana manusia masih teribat di dalamnya, namun beritagar.id tidak memiliki konteks tersebut, sehingga dapat dikatakan bahwa beritagar.id bukan produk jurnalistik. Namun konsekuensi yang ditetapkan dalam UU ITE dan Kode etik wartawan menetapkan hal ini masih dalam ranah jurnalistik.

Media siber adalah segala bentuk media yang menggunakan wahana internet dan melaksanakan kegiatan jurnalistik, serta memenuhi persyaratan Undang-Undang Pers dan Standar Perusahaan Pers yang ditetapkan Dewan Pers. Baik media siber pertama sebagai pembuat dan penyaji maupun media siber ke dua, ketiga dan seterusnya sebagai media yang mengutip dari media siber pertama, tidak luput dari konsekuensi hukum dan etika media massa. Pedoman pemberitaan media siber melihat, segala bentuk media berbasis internet dengan melakukan kegiatan jurnalistik untuk memenuhi persyaratan undang-undang pers dan standar perusahaan pers yang ditetapkan Dewan Pers harus memiliki kriteria yaitu melaksanakan kegiatan jurnalistik, melahirkan produk jurnalistik, dikelola oleh jurnalis profesional dan pemberitaan harus dilakukan verifikasi. Al dalam beritagar tidak melakukan verifikasi, mereka hanya mengumpulkan kata yang sama kemudian menampilkan kecenderungan yang ada dan keterkaitan antar berita yang ada.

Hasil wawancara dengan beberapa informan tentang adanya profesi agregasi berita dalam ranah jurnalistik, sesuai dengan hasil kajian dokumen tersebut, mereka menyatakan bahwa: Informan 1, yaitu jurnalis senior media mainstream yang telah bekerja selama 30 tahun dan tidak memiliki pengalaman bekerja di bidang lainnya mengatakan:

“Aggregator berita itu bukan jurnalis karena mereka tidak mengindahkan elemen jurnalisme dank ode etik jurnalistik. Mereka hanya mencari keuntungan untuk mereka sendiri tanpa melihat hak cipta dan proses jurnalistik yang telah dilakukan oleh jurnalis media yang mereka curi beritanya." 
Nada serupa juga disampaikan oleh Informan 2, seorang jurnalis senior yang telah bekerja 25 tahun sebagai jurnalis baik di media mainstream maupun di media online, menjelaskan:

"Aggregator berita bukan jurnalis dan pekerjaan mereka bukan di ranah jurnalistik. Mereka hanya penyedia data saja bagi jurnalis. Crownnya jurnalisme adalah cek-ricek, mereka tidak melakukanitu sehingga tidak bisa dibilang jurnalis."

Namun pendapat informan 3, yang dahulunya bekerja di media mainstream yang sama dengan informan 1, namun kemudian menjadi pemimpin redaksi di beritagar.id mengatakan bahwa:

"Saat ini jurnalistik harus dipahami berbeda dengan jaman dahulu, di mana reporter harus pergi sendiri ke tempat peristiwa untuk mendapatkan informasi yang patut dijadikan berita. Saat ini di mana berlimpahnya informasi, jurnalistik juga harus mengarah pada pencarian data melalui $\mathrm{Al}$, bukan saja melalui manusia jalan kian kemari. Namun memang keduanya, Al dan manusia, perlu diberikan input agar bisa memberikan informasi yang akurat dan bukan hoax. Menurut saya beritagar.id memberikan warna baru bagi jurnalisme. Mereka berada dalam ranah jurnalisme, tapi memang masih perlu waktu untuk bisa mengidentifikasi faktor perasaan yang banyak muncul ketika berbicara tentang etika dan kode etik. Komputernya masih perlu banyak belajar soal etika dan kode etik".

Dari ketiga pendapat informan tersebut, ketiganya memiliki kesamaan persepsi tentang perlunya faktor manusia dalam menyajikan berita ketida berhadapan dengan kode etik dan etika jurnalistik. Namun kedua informan yang menyatakan proses jurnalistik melalui Al bukan di ranah jurnalisme berbeda dengan informan ketiga yang menyatakan bahwa mereka tetap beraa di ranah jurnalisme mengingat jurnalisme adalah memberikan informasi pada publik sesuai dengan peristiwa yang sungguh terjadi. Hanya, informan ketiga, mengakui perlu waktu bagi Al komputer dalam mempelajari kode etik dan etika jurnalisme.

Nilai-nilai jurnalisme seperti cek dan ricek dianggap oeh ketiga informan sebagai hal penting dalam jurnalisme, namun pelaksanaannya dari ketiga informan dilakukan dengan proses yang berbeda. Cek-ricek oleh informan 1 dan 2 dilakukan oleh manusia, sedangkan informan ketiga dilakukan oleh Al. Sepuluh elemen jurnalisme oleh ketiga informan merupakan nilai jurnalisme yang perlu dipegang teguh oleh jurnalis dalam perannya sebagai watchdog dan ketiga informan menyatakan bahwa mereka tetap menjalankan ke 10 elemen jurnalisme tersebut, bedanya adalah yang melakukannya adalah manusia saja menurut informan 1 dan 2, sedangkan menurut informan 3 adalah melibatkan program Al dan manusia.

Media siber wajib mencantumkan syarat dan ketentuan mengenai isi buatan pengguna yang tidak bertentangan dengan Undang-Undang No. 40 tahun 1999 tentang Pers dan Kode Etik Jurnalistik, yang ditempatkan secara terang dan jelas. Media siber wajib menyunting, menghapus, dan melakukan tindakan koreksi setiap isi buatan pengguna yang dilaporkan dan melanggar ketentuan butir (c), sesegera mungkin secara proporsional selambatlambatnya $2 \times 24$ jam setelah pengaduan diterima. Hal ini menurut informan 3 dapat dilakukan dengan cepat oleh Al dan redaksi menyediakan tempat atau laman atau halaman untuk hal tersebut, dan bisa kurang dari 24 jam.

Namun memang Al perlu diberikan input dahulu tentang hal-hal yang menjadi masalah dan tidak menjadi masalah, agar Al dapat menarik isu yang tepat dan memberikan solusi yang tepat. Al pada prinsipnya sama dengan manusia, mereka perlu belajar dulu dengan memberikan input, lalu manusia memberikan arahan-arahan agar Al bisa melanjutkan arahan tersebut. Jadi proses jurnalistik, menurut informan 3, mengalami pengembangan proses; yang tadinya reporting dilakukan oleh manusia, saat ini dengan adanya Al dapat dilakukan oleh mesin. Namun sebelum itu, jika jurnalis perlu hadir dalam rapat redaksi untuk mendapatkan arahan tentang data yang harus diambil, maka Al prosesnya memasukkan data-data yang kita perlukan lalu mendidik pola data mining agar kemudian mereka bisa menjalankan sendiri pengambilan datanya. Lalu menampilkan hasilnya.

Informan 3 mengakui bahwa di beritagar.id, program Al menjalani proses pembelajaran makna terlebih dahulu dengan memasukkan data lebih dati 50 ribu untuk kemudian dipelajari dengan koridor kode etik jurnalistik, data yang dihasilkan kemudian memang perlu dikonfirmasi dengan adanya reportasi atau wawancara kepada narasumber, dan diberikan angle untuk dapat menampilkannya sesuai dengan kebijakan redaksi. 
Mengenai pencabutan berita, berita yang sudah dipublikasikan tidak dapat dicabut karena alasan penyensoran dari pihak luar redaksi, kecuali terkait masalah SARA, kesusilaan, masa depan anak, pengalaman traumatik korban atau berdasarkan pertimbangan khusus lain yang ditetapkan Dewan Pers. Media siber lain wajib mengikuti pencabutan kutipan berita dari media asal yang telah dicabut dan pencabutan berita tersebut wajib disertai dengan alasan pencabutan dan diumumkan kepada publik. Mengenai hak cipta, media siber wajib menghormati hak cipta sebagaimana diatur dalam peraturan perundang-undangan yang berlaku. Menurut informan 1 dan 2, beritagar.id beritanya belum memperhatikan hal ini, sehingga sensitifitasnya kurang. Hal ini diakui oleh informan 3, dan memang masih banyak hal yang harus di-supply dalam program Al dalam rangka memenuhi Pedoman Pemberitaan Media Siber ini secara terang dan jelas bagi Al.

Terkait menampilkan link-link berita yang diagregasi oleh beritagar.id. Informan 1 dan 2 menyatakan bahwa beritagar tidak memiliki etika karena menulis ulang dari berita yang ada kemudian menjualnya kembali untuk mendapatkan profit. Sementara informan 3, menyatakan sebenarnya hal ini tidak boleh dilakukan, link yang dikutip seharusnya disertakan dan hanya hasil analisis data yang tidak disertakan link-nya karena data tersebut memang hasil olahan beritagar.id dari dokumen yang dipublikasi kepada publik kemudian kami berikan angle serta ditambah dengan konfirmasi pada narasumber melalui wawancara. Informan 3 menyatakan bahwa beritagar.id memerhatikan klausul penyebaran Konten berita adalah hak eksklusif pencipta yang timbul secara otomatis berdasarkan prinsif deklaratif setelah suatu ciptaan diwujudkan dalam bentuk nyata tanpa mengurangi pembatasan sesuai dengan ketentuan peraturan perundangundangan. Kalimat konsep dalam undang-undang ini perlu mengalami proses penerjemahan lebih dulu dalam jurnalisme di beritagar.id karena melibatkan Al. la mengatakan:

"Kalimat dalam Undang-undang itu kan konsep, jadi perlu kita turunkan dulu dalam indikator lalu masukkan dalam proses belajar Al, untuk kemudian program yang menjalankan. Hal ini yang baru dari proses jurnalistik tradisional yang seratus persen dilakukan oleh manusia. Sehingga hak ekonomi (economic right) dan hak moral (moral right) dapat dideteksi oleh Al."
Hasil wawancara tersebut kemudian diabsahkan dengan data yang diambil peneliti dari analisis isi media beritagar.id. Hasil analisis isi media disusun dengan mengambil informasi yang ditampilkan lalu dianalisis oleh peneliti berurutan dalam beberapa data. Pada gambar 1 terlihat bahwa Beritagar.id mengambil beberapa berita tentang peristiwa pertandingan bola dari beberapa media lain, lalu menuliskan ulang dengan menampilkan sumber berita-sumber berita yang dirujuknya yaitu Kompas.com dan Superball. Liputan tersebut juga menayangkan linkback-nya yang ditunjukkan dengan warna biru yang dapat diakses langsung oleh pembaca beritagar.id. Pada gambar 1 , Informan 3 mengatakan:

"...kami menulis ulang tapi kami menampilkan linkback-nya mengikuti kode etik."

Ketika dikonfirmasi hasil analisis isi berita yang tidak memberikan linkback, maka informan 3 menggambarkan bahwa Beritagar.id melakukan peran sebagai aggregator dan curator berita, dan kedua peran ini berbeda dalam penyajian beritanya sesuai yang ditampilkan pada gambar 1 dan 2 .

Gambar 2.

Berita Hasil Agregasi di Beritagar.id

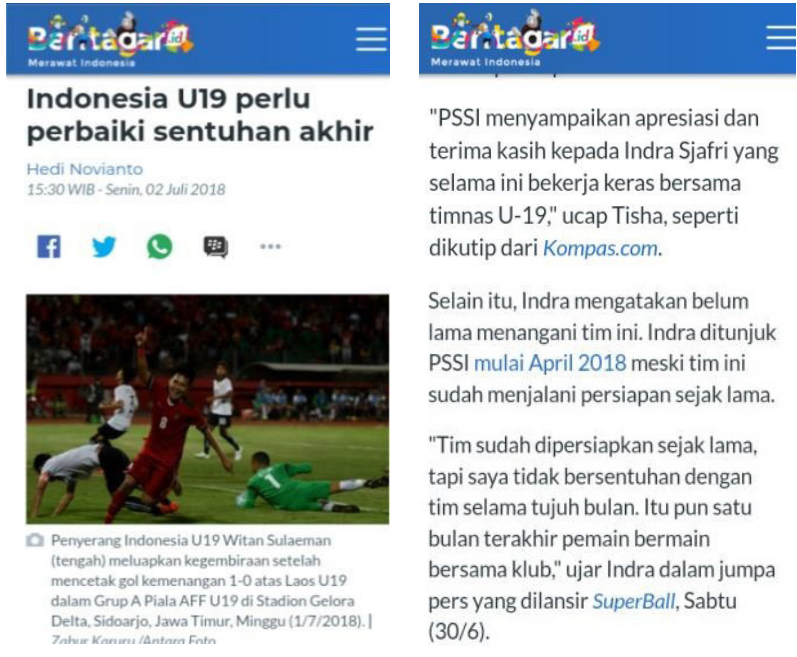

(Sumber: http://beritagar.id)
(30/6).

"PSSI menyampaikan apresiasi dan kasih kepada Indra Sjafri yan timnas U-19" ucap Tisha, seperti dikutip dari Kompas.com sudah menjalani persiapan sejak lama.

"Tim sudah dipersiapkan sejak lama, api saya tidak bersentuhan dengan in bersama klub," ujar Indra dalam jump 
Gambar 3.

Berita Hasil Kurasi di Beritagar.id

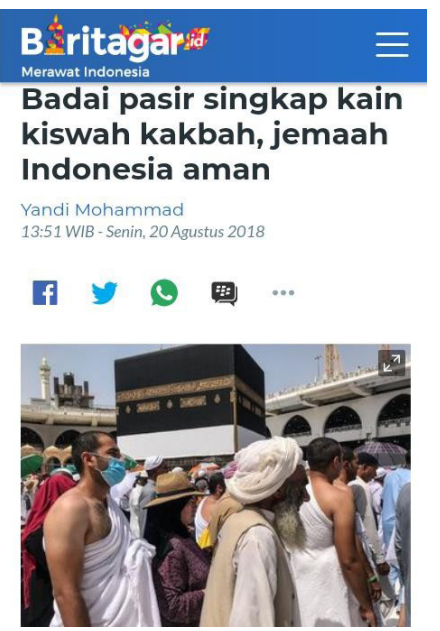

$$
\begin{aligned}
& \text { Bärritagalyid } \\
& \text { Merawat ndonesia } \\
& \text { Setiap tahun kain Kiswah ini diganti } \\
& \text { ketika para jemaah haji berada di } \\
& \text { Arafah dalam rangkaian ibadah haji. } \\
& \text { Pergantian kain kiswah tahun ini } \\
& \text { berlangsung pada Senin (20/8/2018), } \\
& \text { sehari setelah badai terjadi. } \\
& \text { Badai pasir dan hujan diperkirakan } \\
& \text { masih akan terjadi di Arafah hingga } \\
& \text { Senin (20/8/2018) diwarnai } \\
& \text { kelembapan dan suhu tinggi. Menurut } \\
& \text { prakiraan Badan Meteorologi Arab } \\
& \text { Saudi, badai pasir dan hujan berpotensi } \\
& \text { terjadi sampai Senin malam. } \\
& \text { "Ambil saja hikmahnya. Dengan } \\
& \text { kejadian seperti ini kan membuat kita } \\
& \text { menjadi terus istighfar," ujar Khoirizi } \\
& \text { melalui Detikcom. }
\end{aligned}
$$

(sumber: http://beritagar.id)

Menurut semua informan, mereka sepakat bahwa Beritagar.id masuk ke dalam media baru karena mereka membuat berita sendiri dengan kurasi konten berita dengan menganalisis untuk dilakukan verifikasi dan kemudian disatukan dengan data yang di miliki oleh Beritagarid. verifikasi yang dilakukan oleh Beritagar.id adalah menggunakan sumber seperti kompas.com, superball dan okezone. com sebagai verifikasi mereka. Hal ini membuat sebuah hasil di mana Beritagar.id merupakan media aggregasi yang membuat konten sendiri, dengan cara mengurasi sumber berita di media online.

Hanya implikasinya yang berbeda, bagi informan 1 dan 2 hal ini merugikan media mereka, sementara bagi informan 3 hal ini sama dengan proses jurnalistik tradisional di mana semua jurnalis memiliki data yang sama namun memiliki angle yang berbeda. Namun menurut informan 1 dan 2: News aggregator adalah media aggregasi yang menyebarkan berita didalam sebuah media sosial. News aggregator bukan media pers, mereka hanya mengambil berita dari media lain dan disebarkan oleh mesin yang dinamakan aggregasi berita. Namun informan 3 mengaku bahwa:

“...aggregator mengambil berita atau kerjasama dengan media- media lain terus mereka mengambil berita dan memilih mana yang akan dimunculkan di situs mereka." (informan 3, dari beritagar, 17 Juli 2018). Selain itu, informan 3 juga menambahkan bahwa: “... konten aggregator meskipun dia ambil, dia harus menyempurnakan juga proses selecting dengan menambahkan variabel-variabel dan dimesi supaya berita yang teraggregasi itu adalah bener-bener konten dari media-

media yang kredibel saja, kami berhati-hati agar tidak menjadi agen penyebaran kontenkonten yang tidak bertanggung jawab, atau hanya menguntungkan kelompok-kelompok kepentingan tertentu." (informan 3, 3 Juli 2018).

Dari ketiga informan semua sepakat bahwa proses jurnalistik itu memiliki proses reporting dalam arti mengumpulkan data dari peristiwa yang akan ditulis, lalu memilih apa yang akan diangkat dengan angle tertentu, lalu melalukan proses menulis, editing, lalu penyajian kepada publik. Namun perbedaannya ketika reporting dan editing, di mana menurut informan 3 mesin atua program komputer dan Al terlibat di dalamnya, sementara informan 1 dan 2 menyatakan bahwa hal itu masih penting dalam menunjukkan adanya unsur terkait moral dan ekonomi.

\section{Gambar 4.}

Konten Berita yang Memiliki 3 Sumber

Merawat indonona
Selain itu, Indra mengatakan belum
lama menangani tim ini. Indra ditunjuk
PSSI mulai April 2018 meski tim ini
sudah menjalani persiapan sejak lama.
"Tim sudah dipersiapkan sejak lama,
tapi saya tidak bersentuhan dengan
tim selama tujuh bulan. Itu pun satu
bulan terakhir pemain bermain
bersama klub," ujar Indra dalam jumpa
pers yang dilansir SuperBall, Sabtu
(30/6).

(Sumber: http://beritagar.id)

Berita dalam gambar 3 juga menjadi dokumen yang dianalisis, dan hasilnya adalah beritagar.id selalu menampilkan rata-rata 3 sumber dalam 1 berita. Terlihat sumber yang menjadi rujukan pada gambar 3 adalah kompas.com, superball, dan okezone. Menanggapi hal ini seluruh informan menyatakan bahwa berita tersebut tetap menunjukkan adanya usaha dilakukannya verifikasi data atau cek-ricek. Informan 1 dan 2 ketika ditunjukkan detil ini menyatakan bahwa merek baru memperhatikan hal-hal elemen jurnalismen dalam berita yang ditampilkan beritagar.id.

Sementara informan 3 menyatakan bahwa beritagar.id memiliki kebijakan redaksi bahwa berita minimal memiliki 3 sumber yang kredibel untuk 1 tulisan. Beritagar.id yang menurut informan 1 dan 2 dianggap memiliki implikasi negatif pada media di 
mana mereka bekerja, dalam penelitian ini, ketika ditunjukkan nilai-nilai jurnalisme yang dilakukan oleh beritagar.id terlihat ada perbedaan persepsi yang dimiliki oleh kedua informan. Mereka mulai memikirkan bahwa news aggregator, khususnya beritagar.id ini termasuk dalam praktek jurnalisme yang memperhatikan nilai-nilai jurnalisme, meski kedua informan menyatakan bahwa dari sisi Dewan Pers masih belum ada kejelasan tentang posisi beritagar.id ini.

\section{SIMPULAN}

Simpulan yang dapat diambil dari penelitian ini adalah, saat ini mesin telah mengintervensi proses jurnalistik dengan program Al. Mesin berita ini dapat membantu permasalahan dalam redaksi terkait dengan kecepatan up to date per detik. Limpahan informasi yang setiap detiknya muncul di internet melalui beragam media, baik mainstream online, portal, maupun media sosial, membuat publik menjadi memiliki kemewahan informasi sekaligus kebingungan memilih informasi. Media online yang bernama news aggregator dengan kelebihan dapat mendistribusikan konten berita dari berbagai situs berita muncul dengan implikasi mempermudah individu mencari informasi serupa dan yang terkait, namun dalam jurnal yang dibuat oleh Joan dan Ricard (2017) mengenai apa yang dilakukan aggregator berita dengan bukti dari google news di Spanyol dan German, menyatakan bahwa adanya efek positif dan negatif yang diterima oleh media lainnya. Terjadinya perluasan pasar berita merupakan implikasi positif, namun turunnya pengunjung serta iklan merupakan implikasi negatifnya.

Bila di Eropa telah ada solusi bisnis antar kantor agregasi berita dan media yang dirujuk dan ditarik datanya, di Indonesia Dewan Pers pun masih bingung memutuskan mengenai fenomena ini, namun satu hal yang saat ini masih diakui adalah adanya anggapan bahwa aggregator bukan bagian dari produk jurnalistik karena mereka dianggap tidak membuat berita, dan tidak melakukan liputan langsung ke lapangan. Minimal 3 sumber yang disajikan oleh beritagar.id, diakui oleh dua informan merupakan indikasi dilakukan verifikasi, meski mereka juga ragu untuk menetapkan bahwa hal itu benar adanya mengingat perlu adanya perjanjian bisnis terlebih dahulu antara beritagar.id dengan media-media yang dirujuk dan ditulis ulang informasinya meski linkback berita yang dirujuk telah diletakkan dalam online. Diskusi masih berlanjut terkait etika moral dan ekonomi di Indonesia pada aggregator berita, dan hal ini juga terjadi di negara maju lainnya.

\section{DAFTAR PUSTAKA}

Anom, E. (2013). Regulasi dan Kebijakan Media Cetak di Indonesia Masa Zaman Penjajah. Jurnal Komunikologi, Vol. 10 No. 2, 73-79, FIKOM Universitas Esa Unggul Jakarta.

Athey, S. Markus, M. dan Jeno, P. (2017). The Impact Of Aggregators On Internet News Consumption. Stanford Business School and NBER.

Beritagar.id. (2018, 02 Juli). Indonesia U19 Perlu Perbaiki Sentuhan Akhir. Retrieved Juli 02, 2018, from http://beritagar.id/Indonesia-U19Perlu-Perbaikan-Sentuhan-Akhir

Beritagar.id. (2018, 17 Juli). Dugaan Suap PLTU Riau1 tak Ganggu Megaproyek 35 ribu MW. Retrieved Juli 17, 2018, from http://beritagar. id/dugaan-suap-PLTU-riau-1-tak-ganggumegaproyek-35- ribu-mw.

Beritagar.id. (2018, 03 Juli). Home Beritagar.id. Retrieved Juli 03, 2018, from http://beritagar. id/home.

Calzada, J. dan Gill, R. (2017). What Do News Aggregator Do? (Evidence From Google News In Spain And Germany). Universitat De Barcelona.

Coddington, M. (2019). Aggregation and Journalism. Ebook: Feb 2019.

Dwiputra, O. S. (2011). Aspek Hukum Laman Pengumpulan Berita (News Aggregator Website) yang Menggunakan Karya Jurnalistik dalam Bentuk Berita Media Online di Kaitkan dengan Perlindungan Hak Cipta. Bandung: Universitas Padjadjaran.

Himawan, Q. I. (2011). Soal Etika dalam Jurnalisme Online. Dewan Pers.

Hanitzsch, T. (2005). Journalists in Indonesia: Educated but timid Watchdogs. 6(4), Journalism studies, pp. 493-508.

Hanitzsch, T. (2006). Mapping Journalism Culture: A Theoretical Taxonomy and Case Studies From Indonesia, Asian Journal of Communication, 16(2), 169-186, DOI: 10.1080/01292980600638835.

Isbell, K. (2010). The Rise of the News Aggregator: Legal Implications and Best Practices. Harvard, Amerika Serikat : Berkman Center for Internet and Study. 
James, C. (2005). Online Journalism: Principles and Practices of News For the Web. Inggris: Foust Holcomb.

Kakiailatu, T. (2007). Media In Indonesia: Forum for Political Change and Critical Assessment. Asia Pacific Viewpoint, 48(1), 60-71.

Pavlik, J.V. (2001). Journalism and New Media, New York USA: Columbia University Press.

Pers, D. (2018, 19 Juli). Data Perusahaan Pers Beritagar.id. Retrieved Juli 19, 2018, from http://dewanpers.or.id/data/perusahaanpers.

Pers, D. (2018, 09 Juli). Pedoman Pemberitaan Media Siber. Retrieved Juli 09, 2018, from http://dewanpers.or.id/kebijakan/ pedomanReferensi.

Ulfah, F. R. (2017). Penerapan Jurnalisme Robot dalam Proses Produksi Berita di Beritagar.id. Bandung: Universitas Padjadjaran.

Wendratama, E. (2017). Jurnalisme Online: Panduan Membuat Konten yang Berkualitas. Yogyakarta: Bentang. 